\title{
Life Endangerment - A Paramount Condition in Forensic and Judicial Practice
}

\author{
Carmen Corina Radu, Timur Hogea*, Dana Doroftei, Cosmin Carașca \\ George Emil Palade University of Medicine, Pharmacy, Science, and Technology of Targu Mures, Romania
}

Life-threatening injuries represent those types of lesions that certainly lead to the victim's death if no qualified medical care is applied in due time. We hold important the aspect of imminent danger, and that the lesion, in its natural way of evolution, will determine the person's death, his life being saved only by a qualified medical intervention. The juridical correspondent is represented in article 194: bodily harm - The new criminal code and the new criminal procedure code. The authors review and comment on the main particular aspects of life-threatening traumas, based on topography, anatomical aspects and forensic interpretation, in order to offer arguments to be incorporated from a medico-legal point of view, reported to the criteria of life-threatening conditions. We shall illustrate the subject by 6 case reports.

Keywords: forensics, trauma, life-threatening conditions

Received 27 July 2021 / Accepted 10 September 2021

\section{Introduction}

In accordance with the criminal law stipulations, regardless of the medical care duration, the post-traumatic lesions can also be categorized as severe by the life-threatening status they posses. Severe bodily injuries by life-threatening conditions are stipulated in article 194 of the Criminal law and are based on acts that lead to physical integrity or health alteration, an injury that has as consequence life-threatening conditions, and is punishable by 2 to 7 years of imprisonment [1]. This aspect is decided only by medico-legal expertise, the vital risk being defined by the severity of the lesions or their complications that can lead to death, which must be greater than the body's natural healing ability. Thus, life-threatening lesions have at least one of the next characteristics: great severity, which in the absence of proper therapeutical care have an immediate death risk; major complications can appear during the evolution of these lesions, leading to the person's death (tardive risk). The great variety of human body reactivity reveals that in some cases, even though the severity of the lesion is great, usually deadly, healing can occur without life-threatening conditions at any time, while in other cases, a relatively mild injury can lead to severe life-endangering complications or even death -directly or based on some underlying conditions [2,3].

The aim of this paper is to clarify the life-threatening notion for a better understanding among practitioners and implicitly a better forensic assessment.

\section{Methods and material}

We will present a synthesized version of the main anatomical and clinical posttraumatic entities, which will be addressed mainly by their evolution, to offer classifying medico-legal arguments regarding life-threatening conditions, by reviewing 6 representative cases, assessing the character- istics of the traumatic lesions, the medical care implied, the generating mechanisms and the differences between life endangering and non-life endangering traumas by closely following the vital function of the patients in the moment of examination, the evolution and medical care applied.

\section{Case reports}

For a better understanding of the subject we shall proceed by presenting the following case reports:

\section{Case report 1}

Male, 71 years old, traffic accident victim, pedestrian. He is urgently hospitalized with the diagnosis: "Multiple trauma due to traffic accident. Craniocerebral trauma. Rib fractures VI-XII. Subcutaneous emphysema. Hemopneumothorax. Right radius and ulna diaphyseal fracture. Multiple wounds". The medical chart showed that chest drainage was performed for the hemopneumothorax, as the values of hemoglobin and hematocrit were $7,57 \mathrm{~g} / \mathrm{dl}$, respectively $26,7 \%$ and the $\mathrm{O} 2$ saturation was $92 \%$; erythrocyte mass, physiological saline, and glucose were administered. The medico-legal report of expertise concluded that the traumatic lesions were life-threatening.

\section{Case report 2}

Female, 62 years old, assaulted by her husband, is urgently hospitalized with the following diagnosis:" Multiple traumas. Craniofacial trauma with soft tissue lesions. Thoracic trauma presenting ecchymosis, hematoma and multiple rib fractures. Flail chest, displaying acute respiratory failure symptoms with an $\mathrm{O} 2$ saturation of $86 \%$ ". Emergency surgery is performed in order to fix the flail chest. The conclusions of the medico-legal expertise report: the traumatic lesions were life-threatening. 


\section{Case report 3}

Male, 30 years old, assault victim, suffering a direct leg kick in the left abdominal area. He is urgently hospitalized with the following diagnosis:"Posttraumatic spleen rupture and hemoperitoneum". Splenectomy is performed, the evolution is favorable and he is discharged in 10 days. The medico-legal expertise report concluded that the traumatic lesions were life-threatening.

\section{Case report 4}

Male, 55 years old, victim of a stabbed wound. He is hospitalized with the following diagnosis:" Pointed/cut wound on the left precordial region". The local examination showed the thoracic wall presenting a vertical wound, having a sharp and an obtuse angle, smooth edges, the stab wound size being consistent with the knife, presenting a perforating lesion of the pericardium, associated with pneumomediastinum. Immediate surgery followed by suturing of the wound is performed. The conclusions of the medico-legal expertise report: the traumatic lesions were life-threatening, and juridically assessed as attempted murder.

\section{Case report 5}

Woman, 35 years old, victim of a burglary, blunt force trauma to the head. She is urgently hospitalized and has the following diagnosis:"Craniocerebral trauma. Linear right parietal fracture. Minimal extradural hematoma. Subarachnoid hemorrhage with no intracranial hypertension and no meningeal signs. Glasgow coma scale (GCS) 15 points". Favorable evolution with resorption of the blood collections under conservative treatment. The medico-legal expertise report concluded that the traumatic lesions were not life-threatening.

\section{Case report 6}

Male, 35 years old, falls while fixing the roof of his house and is found passed out by his family. He is urgently hos- pitalized with the following diagnosis:"Severe craniocerebral trauma, comatose state. Glasgow coma scale 5 points. Skull fracture. Diffuse cerebral hemorrhage and concussion". Orotracheal intubation was performed. A medicolegal examination is requested and the forensic pathologist arrives at the hospital to examine the victim. The conclusions of the medico-legal expertise report: the traumatic lesions were life-threatening.

In the previous cases we assessed the vital functions in the moment of examination, the evolution and treatment needed. The alteration of any vital function is a key marker in the evaluation of severity in traumas. Analyzing the cases presented, we find that life endangerment was considered due to hemorrhage, desaturation, pneumomediastinum and craniocerebral trauma with associated comatose, in each case the patient requiring emergency surgery or intensive care support to improve vital functions. For the case report no.5, although the patient presented with a significant craniocerebral trauma, the state of consciousness was maintained, the traumatic injuries did not affect the vital status and the patient did not require surgical or intensive supportive treatment, so life endangerment was not sustained (Table I).

\section{Discussions}

From a medico-legal point of view the division of the body in vital and non-vital areas is not always a relevant fact in establishing the life-threatening conditions, because there are many known cases in which the injury was applied in regions that don't affect vital organs, but still lead to death. On the other hand, cases in which sharp-impaling objects were used on vital areas, resulting in superficial wounds, without damaging the underlying organs, were not considered life-threatening conditions. Thus, we have to keep in mind that a correct description of lesion morphology, a comprehensive assessment of the case, medical records, clinical and local examination, surgical and other special-

Table I. Representative characteristics of the 6 cases

\begin{tabular}{|c|c|c|c|}
\hline Case no. & Lesions & Treatment & Life endangerment \\
\hline 1 & $\begin{array}{l}\text { - subcutaneous emphysema } \\
\text { - hemopneumothorax } \\
\text { - hemoglobin: } 7.57 \mathrm{~g} / \mathrm{dl} \\
\text {-hematocrit: } 26.7 \% \\
\text { - O2 saturation: } 92 \%\end{array}$ & $\begin{array}{l}\text { - chest drainage } \\
\text { - erythrocyte mass }\end{array}$ & + \\
\hline 2 & $\begin{array}{l}\text { - fail chest } \\
\text { - acute respiratory insufficiency } \\
\text { - O2 saturation: } 86 \%\end{array}$ & - surgical stabilization of the flail chest & + \\
\hline 4 & $\begin{array}{l}\text { - pointed/cut wound on the left } \\
\text { precordial region } \\
\text { - pneumomediastinum } \\
\text { - perforating lesion of the pericardium }\end{array}$ & - surgery & + \\
\hline 5 & $\begin{array}{l}\text {-craniocerebral trauma } \\
\text { - linear right parietal fracture } \\
\text { - minimal extradural hematoma } \\
\text { - subarachnoid hemorrhage } \\
\text { - no intracranial hypertension } \\
\text { - no meningeal signs } \\
\text { - Glasgow coma scale: } 15 \text { points }\end{array}$ & - conservative treatment & - \\
\hline 6 & $\begin{array}{l}\text { - craniocerebral trauma } \\
\text { - skull fracture } \\
\text { - Glasgow coma scale: } 5 \text { points }\end{array}$ & - orotracheal intubation & + \\
\hline
\end{tabular}


ties consults are paramount for the forensic pathologist to clearly understand the patient's condition (Table II).

Topographically, craniocerebral trauma imply soft tissue lesions, bone lesions, and lesions of cranial vault contents. The major physio pathological consequences that can lead to life-threatening situations are coma, traumatic and hemorrhagic shock, hemorrhages, meningocerebral concussions and lacerations, cerebral hypoxia [4]. According to Vilalta J et al, in cases of severe craniocerebral injuries, the predictive mortality factors are a low Glasgow scale, intraventricular hemorrhage and mydriasis [5]. These factors being imperative in the initial examination of severe head traumas. In modern medical practice, the evaluation of the patient's state is assessed by algorithms using traumatology severity scores that can estimate the mortality [6]. According to Turculet $\mathrm{C}$ et at, the use of both physiological and anatomical severity scores should be performed in order to get a clear traumatic lesion evaluation. [7] (Table III). Neck trauma can be categorized by the integrity of the soft tissues in blunt and penetrating traumas. The following major physio pathological consequences that can lead to life-threatening conditions are external hemorrhages, mechanical asphyxia, air embolism. Edged weapons lead to deep wounds, affecting the muscles and sometimes the laryngeal cartilages or the upper part of the trachea, or in cases where great force is applied even the spine. The lesion on the blood vessels leads to massive external hemorrhages. $40 \%$ of the most common cause of deaths in neck trauma are due to vascular injuries, and the most often cause of delayed mortality is due to esophageal injuries [8]. Rathlev NK et al. evaluate the life-threatening aspect of these injuries due to their severe complications on the aerodigestive and vascular structures of the neck, injuries that are challenging even for skilled practitioners and the multiple approaches needed to lower the mortality rate in this cases. [9]. Mahmoodie M et al. also reviewed 192 cases of neck trauma in a 10 years span, revealing that the most frequent cause of penetrating neck traumas were stab wounds, and assessing the complications associated with this lesions together with the importance of early neck exploration in deep injuries and unstable cases, in order to reduce the mortality of these injuries. [10] (Table IV). In patients with head and neck traumas, the risk of secondary complications such as embolism or strokes is high if not handled properly [11]. Thoracic traumas can be classified as blunt (affect the walls of the thoracic cavity: soft tissues, skeleton, and the viscera) and penetrating (wounds that are caused by sharp/pointed objects, rarely firearms). Visceral lesions in thoracic traumas are classified as life-threatening lesions, respectively considered attempted murder from the juridical point of view. Lesions caused by edged weapons in the thoracic area raise differential diagnosis problems concerning the way that it occurs (self-inflicted or caused by someone else). In cases of thoracic traumas, the major physio pathological consequences that can lead to life-threatening conditions are internal hemorrhage, hemorrhagic and traumatic shock, acute respiratory failure in thoracic traumas with rib fractures and flail chest. (Table V). Cardiac or blood vessel injuries are immediately life threatening, but also flail chest and lung laceration/contusions can lead to severe complications, having a high mortality rate if bilateral, but also leading to prolonged ventilation and complications even if unilateral [12]. Blunt abdominal and pelvic traumas can include lesions of the abdominal wall without affecting the parietal peritoneum, the most frequent causes being strong compression, falling from heights, projection; very often the rupture of parenchymatous intra-abdominal organs occurs, rarely of the hollow organs if they are empty. The particular rupture of intra-abdominal organs is the "two-stage rupture", mostly involving spleen and liver rupture associated with hemoperitoneum. Fomin D et al

Table III. Craniocerebral life-endangering injuries [15].

Epidural haematoma $>50 \mathrm{ml}$
Small subdural hematoma complicated by bleeding or intracranial pressure
Large subdural hematoma
Large subarachnoid hemorrhage
Large intracerebral posttraumatic hemorrhage
Cerebral contusion (Marshall diffuse or severe)
Liquid collections: large cerebrospinal fluid fistulas
Vascular lesions: occlusive vascular syndrome,, arterial-venous fistulas, large
sinus thrombosis, sinus thrombophlebitis.
Large subdural hematoma

Large subarachnoid hemorrhage

Large intracerebral posttraumatic hemorrhage

Cerebral contusion (Marshall diffuse or severe)

sinus thrombosis, sinus thrombophlebitis.

Table II. Soft tissues life-endangering injuries [15].

\begin{tabular}{ll}
\hline Wounds & Burns \\
\hline Penetrating cut wounds & First degree burns on $>60 \%$ of body surface \\
Penetrating punctured wounds & Second degree burns on $>30 \%$ of body surface \\
Penetrating punctured-cut wounds & Third degree burns on $>20 / 30 \%$ of body surface \\
Penetrating laceration & Fourth degree burns on over $3-15 \%$ of body surface \\
Split wounds with massive hemorrhage & \\
Perforating/penetrating shot wounds - type V/VI/VII & \\
\hline
\end{tabular}

Table IV. Other life-endangering injuries [15].

\begin{tabular}{|c|c|c|}
\hline Vascular traumas & Neck structures & Hollow organs \\
\hline $\begin{array}{l}\text { Vascular ruptures in large or small/medium blood ves- } \\
\text { sels if they lead to one of the following complications: } \\
\text {-massive hemorrhage with blood transfusions } \\
\text {-posttraumatic pseudoaneurysm/aneurysm } \\
\text {-hemorrhaging syndrome }\end{array}$ & $\begin{array}{l}\text { Tracheal wounds that can lead to pneumo- } \\
\text { thorax } \\
\text { Laryngeal injuries Schaefer II or above } \\
\text { Epiglottic wounds that lead to glottic edema }\end{array}$ & $\begin{array}{l}\text { Penetrating gastric wounds without the need of resec- } \\
\text { tion, complicated with peritonitis. } \\
\text { Penetrating gastric wounds that need total or subtotal } \\
\text { resection } \\
\text { Intestinal ruptures or perforating wound } \\
\text { Intestinal transection or devitalisation } \\
\text { Bladder explosion }\end{array}$ \\
\hline
\end{tabular}


Table V. Thoracic life-endangering injuries [15].

\begin{tabular}{|c|c|}
\hline Lungs & Heart \\
\hline $\begin{array}{l}\text { Unilateral contusions with pneumothorax leading to acute respiratory } \\
\text { failure } \\
\text { Intrapulmonary hematoma + hemothorax } \\
\text { Persistent/large pulmonary rupture } \\
\text { Lobar/segmental/hilum vascular rupture } \\
\text { Pulmonary hilum transection } \\
\text { Intrapulmonary hematoma } \\
\text { Persistent pulmonary rupture (>72 h) with air loss in distal airways } \\
\text { Severe pulmonary rupture with air loss in segmentary/lobar bronchi } \\
\text { Rupture of segmentary/lobar/hilum blood vessels } \\
\text { Transection of the hilum }\end{array}$ & $\begin{array}{l}\text { Cardiac concussion with acute cardiac insufficency } \\
\text { Contusion, with cardiac arrest } \\
\text { Contusion, with severe EKG modifications } \\
\text { Pericardial traumas with hemopericadium } \\
\text { Trauma that leads to: acute cardiac failure, hemopericardium, pericardial empyema, } \\
\text { cheilopericardium, pneumopericardium } \\
\text { Cardiac contusion complicated with atrioventricular block, ischemia, multifocal ven- } \\
\text { tricular tachycardia } \\
\text { Blunt/perforating cardiac lesions that lead to septal ruptures, valvular failure, papillary } \\
\text { muscles disfunction, distal coronary occlusion } \\
\text { Pericardial wounds/ruptures that lead to heart herniation } \\
\text { Myocardial wounds with no endocardial damage but with cardiac tamponade } \\
\text { Penetrating wounds of the heart chambers/ with proximal coronary artery occlusion } \\
\text { Star shaped wounds that lead to loss of }<50 \% \text { of the heart tissue ( }>50 \% \text { life incom- } \\
\text { patible) } \\
\text { The appearance of the following complications in less severe heart traumas: valvular } \\
\text { lesions, cardiac aneurysm, heart rhythm disorders, septal rupture }\end{array}$ \\
\hline
\end{tabular}

Table VI. Abdominal life-endangering injuries [15].

\begin{tabular}{|c|c|c|c|}
\hline Liver & Spleen & Kidneys & Pancreas \\
\hline $\begin{array}{l}\text { Subcapsular hematoma, Liver } \\
\text { rupture } 1-10 \mathrm{~cm} \text { in length } \\
\text { complicated with hemoperi- } \\
\text { toneum, peritonitis or hepatic } \\
\text { necrosis. } \\
\text { Liver rupture }>3 \mathrm{~cm} \text { deep or } \\
>10 \mathrm{~cm} \text { long } \\
\text { Extensive ruptures }\end{array}$ & $\begin{array}{l}\text { Subcapsular/intraparenchymatous hema- } \\
\text { toma, wound/rupture of the capsule - if com- } \\
\text { plicated with hemoperitoneum or peritonitis. } \\
\text { Capsular wound/rupture }>3 \mathrm{~cm} \text { long with } \\
\text { associated vascular damage } \\
\text { Rupture with extensive vascular damage } \\
\text { (hilum blood vessels-major ischemia) } \\
\text { Complete spleen rupture }\end{array}$ & $\begin{array}{l}\text { Complete kidney rupture/de- } \\
\text { struction } \\
\text { Vascular damage (renal artery/ } \\
\text { vein) } \\
\text { Hilum/ureter avulsion } \\
\text { Urethral ruptures/wounds/ } \\
\text { contusions complicated with } \\
\text { massive hemorrhage/ hemor- } \\
\text { rhagic shock }\end{array}$ & $\begin{array}{l}\text { Pancreatic contusions/superficial wounds/rup- } \\
\text { tures they lead to acute pancreatitis, fistulas, } \\
\text { pseudocysts when surgery needed } \\
\text { Profound wounds/ruptures with no ductal } \\
\text { damage } \\
\text { Distal or proximal transection with ductal } \\
\text { damage } \\
\text { Ductal/ampullar injuries } \\
\text { Pancreatic head destruction }\end{array}$ \\
\hline
\end{tabular}

evaluated 50 cases of isolated spleen rupture through postmortem investigation, studying the difference between the acute/subacute aspect of spleen ruptures. The spleen rupture occurs usually in cases of blunt abdominal traumas. The injury can affect the capsule and the parenchyma simultaneously, leading to hemoperitoneum, massive blood loss and immediate death or it can lead to a subcapsular injury, creating a subcapsular hematoma which enlarges for hours/days until it can lead to a capsular rupture [13] (Table VI). A similar aspect is met in case of rupture of the hollow organs (stomach/intestines), where a small lesion is initially covered by the omentum and the surrounding tissue, but a raise in the internal pressure leads to peritonitis due to the effusion of the contents. According to Nicolau $\mathrm{AE}$ et al, hollow organs perforation due to abdominal traumas have a high death rate, the early diagnosis being very difficult; it is considered that repeated abdominal CT, diagnostic laparoscopy together with clinical examination and imaging are beneficial [14]. Blunt abdominal traumas are dangerous because the severity of the internal lesions isn't consistent with the external ones, being sometimes harder to clinically diagnose. Even violent traumas rarely cause consistent external injuries. Penetrating abdominal traumas are considered to be life-threatening conditions by creating a communication of the peritoneal cavity with the external environment. Regardless of the type of the abdominal trauma, the severity is measured by the presence and type of the intra-abdominal visceral lesions and the echo over the body's homeostasis. Edged weapon lesions (sharp-splitting-pointed weapons) can lead to large blood vessel section with external or internal hemorrhages, peritonitis, visceral rupture, infectious complications. Turculet $\mathrm{C}$ et al. described the abdominal and pelvic trauma by their morphology, location and possible life endangerment status, assessing the importance of combined anatomical and physiological severity scores. [7].

While there has been much research on the subject of traumatic events, few overseas researchers have assessed the aspect of life endangerment. The legislative norms of foreign countries do mention "severe bodily injury" under different articles of law regarding assaults, aggravated assaults and accidents but not as a stand-alone term and this leads to a subjective and vague interpretation of each case.

\section{Conclusions}

The notion of a life-threatening condition/life endangerment is strictly assessed by the severity of the wounds and their effect on the vital functions, injuries that certainly lead to death in the absence of proper emergency medical treatment.

Considering the aspect of variable reactivity of the body and sometimes underlying conditions, the life-threatening status of a lesion is frequently difficult to determine.

A more unified conception in the forensic pathology departments would be preferable.

\section{Authors' contribution}

CCR: conceptualization, data curation, formal analysis, investigation, methodology, project administration, supervision, validation, visualization, writing - original draft, writing - review and editing; TH: data curation, investigation, methodology, validation, visualization, writing - review and editing; DD: conceptualization, data curation, methodology, visualization, writing - review and editing, translation; CC: data curation, investigation, methodology, validation, visualization, writing - review and editing. 
Conflicts of interest.

The authors report no conflicts of interest.

\section{References}

1. Lupașcu D. The new criminal code and the new criminal procedure code. Universul Juridic. București. 2013.

2. Marsden NJ, Tuma F. Polytraumatized Patient. Treasure Island (FL): StatPearls Publishing. 2021 Jan.

3. Bulgaru ID, Scripcaru C, Enache A, Curcă GC. Tratat de traumatologie medico-legală, volumul I. lași. Editura Timpul. 2021.

4. Radu CC. Aspecte medico-legale și etice ale traumatismului cranio-facial. Editura Universității Oradea. 2016.

5. Vilalta J, Vaque J, Olona M, et all. Predictive factors of mortality in severe craniocerebral trauma. Med Clin (Barc). 1992;99(12):441-3.

6. Bilgin NG, Mert E, Camdeviren $\mathrm{H}$. The usefulness of trauma scores in determining the life threatening condition of trauma victims for writing medical-legal reports. Emerg Med J. 2005;22(11):783-7.

7. Turculet C, Dermengiu D, Marinescu M. Medical and forensic criteria for the assessment of abdominal trauma severity. Rom J Leg Med. 2007;15 (2): 141-149.
8. Alao T, Waseem M. Neck Trauma. StatPearls Publishing. Treasure Island (FL). 2021.

9. Rathlev NK, Medzon R, Bracken ME. Evaluation and management of neck trauma. Emerg Med Clin North Am. 2007 Aug;25(3):679-94.

10. Mahmoodie M, Sanei B, Moazeni-Bistgani M, Namgar M. Penetrating neck trauma: review of 192 cases. Arch Trauma Res. Spring. 2012;1(1):14-8.

11. George E, Khandelwal A, Potter $C$ et al. Blunt traumatic vascular injuries of the head and neck in the ED. Emergency Radiology. 2019;26(1):75-85.

12. Huber, S, Biberthaler P, Delhey P. et al. Predictors of poor outcomes after significant chest trauma in multiply injured patients: a retrospective analysis from the German Trauma Registry (Trauma Register DGU®). Scand J Trauma Resusc Emerg Med. 2014;22:52.

13. Fomin D, Chmieliauskas S, Petrauskas V, et all. Traumatic spleen rupture diagnosed during postmortem dissection. A STROBE-compliant retrospective study. Medicine (Baltimore). 2019 Oct;98(40): e17363

14. Nicolau AE, Merlan V, Dinescu G, Crăciun M, Kitkani A, Beuran M. Perforation of hollow organs in the abdominal contusion: diagnostic features and prognostic factors of death. Chirurgia (București). 2012;107(2):162-8.

15. Dermengiu D. Evaluarea gravității leziunilor traumatice-repere axiologice, criteriologice și metodologice. București. Editura Gemma. 2015. 